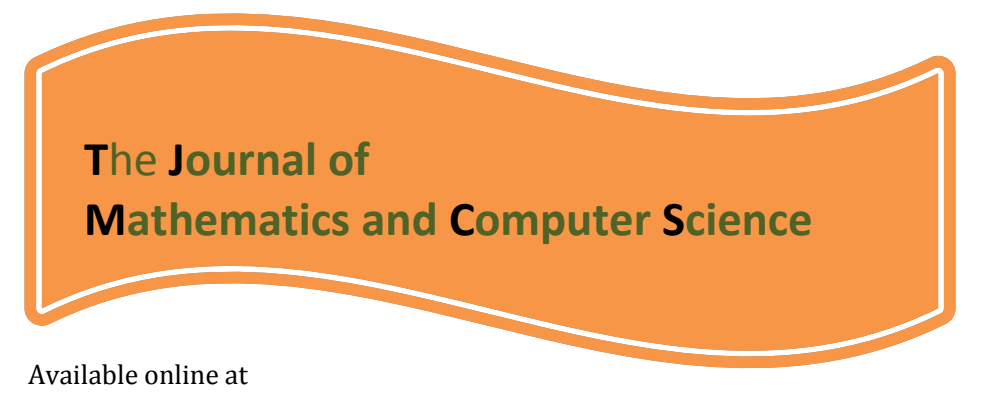

http://www.TJMCS.com

The Journal of Mathematics and Computer Science Vol .3 No.4 (2011) 413 - 421

\title{
Relationship between Organizational Intelligence and Entrepreneurship among University Educational Managers
}

\author{
A. Bakhshian, F. Hamidi, M. Ezati \\ Department of Education, Shahid Rajaee teacher training University, Lavizan, Tehran, Iran \\ aly1347@gmail.com, \\ fhamidi@srttu.edu,ezati.m@gmail.com
}

Received: August 2011, Revised: November 2011

Online Publication: December 2011

\begin{abstract}
Entrepreneurship is one of the important resources in all human societies regarded as one of the most important assets for each country. In todays complicated world those organizations are more important that are having human resources withrich intelligence. This study probes to find the relationship between organizational intelligence and entrepreneurship from the view point of educational managers of Mazandaran University. To this purpose a number of 202 managers were selected through census. This study is descriptive- correlational in nature and the instruments used for data collection are Albercht's Organizational Intelligence questionnaire and Robbins' entrepreneurship questionnaire. Data was analyzed through Pearson Correlation Coefficient, stepwise regression and structural equations were used to find out the relationship between variables. Results of regression analysis showed alignment and congruence had the most direct effect on entrepreneurship, $\beta=0.39, \quad \mathrm{P}<\cdot / \cdot 1)$ and after that heart and appetite for change come. Other variables also have effects on entrepreneurship indirectly and through these three variables. The most indirect effect of variables on dependent variable is pertinent to the performance pressure $(\beta=0.28)$. The analytical model developed in this study for the relationship between variables shows high correlation between organizational intelligence and entrepreneurship.
\end{abstract}

Key words: organizational intelligence, entrepreneurship, educational managers 


\section{Introduction}

In major policies of a country, a lot of attention has been paid to organizational intelligence in recent years to improve entrepreneurship. This is because of the great role of entrepreneurs in the economic development of a country. However, most of the studies done on entrepreneurship took characteristic, structural and environmental situations into account and organizational intelligence as the most important factor was not paid attention to (Ashena,et al 1997). Studies conducted on entrepreneurship were criticized due to disregard to intelligent human sources. The concept of organizational intelligence (OI) came into vogue in academic setting in the 1980s. some of the authors believe that Michael Porter first introduced the concepts of OI and competition intelligence. On the other hand, Carl Albercht is one of the pioneers in designing OI. From the viewpoint of Albercht humans maybe very competent and intelligent for doing great jobs but it is their collective mental power that leads to doing great jobs. based on the science of Physics we can say the loss of this mental power leads to entropy. In thermodynamics is the amount of disharmony in the system, the amount of energy that is not available for generative output. In contrast, we can talk about Synchrony which is an increase in energy or the available mental power. Mathematically speaking, OI includes:

Net intelligence: Synchrony + entropy - total of IQ (available mental power)

In this formula synchrony is an increase in peoples mental powers as a result of Synergistic. Albercht definition of OI is the capacity of an organization for using all its mental powers and the concentration of that mental power on doing its mission. Therefore, based on this definition, the role of OI is simple. It means making an organization more successful in its environment. The belief of the most intelligent organizations is that a good thing is never as good as it should be and we should move to work with thought from work with things(Albercht, 2003). Matsuda from Japan is also one of the creators of the OI and regards OI as a combination of both OI and mechanical intelligence. OI is a learning process and includes a development in adaptive behavior(Choo, 1996, p.18). Minchregards OI as having four features including a)purpose-oriented behaviors, organizational information bases and easy access to them, selection of the right action and its management, overlooking the results (1996, p. 79). Veber (1996, p. 29) defines OI as the ability of an organization in shaping its environment based on its capabilities. Veryard (2000, p. 350) defines OI as a combination of organizational abilities that present intelligent behaviors. From the viewpoint of Halal (1998) OI is the capacity of an organization in creating knowledge and using it to adapt itself to the environment or the market strategically. OI is like IQ but is shaped at an organizational level and like IQ it is measurable. Helal and associates regard OI as a continuum consisting five cognitive subsystems including organizational structure, culture, the relationship among stakeholders, management of science, strategic processes.Mac Master (1996) considers OI as the capacity of an organization in raising information, innovation in general knowledge, effective action based on the creation of knowledge. Albercht (2003) considers OI as having seven items including: 1) strategic perspective. Strategic perspective points to the ability of the organization in the creation, development and statement organizational of objectives; 2) shared fate: the staff cooperate together for the sake of developing each other to reach their perspectives; 3) appetite for change. The word 'change' signifies gaining new and exciting experiences or a chance for starting a new work; 4) heart: in addition to shared fate, the element of heat engages with a tendency to endowment which exceeds the standard level.

Organizational psychologists Pointe to favorable attempts as the energy in organization members to do their jobs. In an organization with low heart, the staff do not do their job and tasks as well as they should do. 5) Alignment and congruence. In intelligent organizations alignment and congruenceis the structure and organizational systems and a combination of 
regulations and rules for the development of group learning and the cooperation of the staff for creating values and realizing the missions of the organization. 6) Knowledge deployment. This factor refers to the capacity that the culture and atmosphere of the organization creates to use its valuable mental and informational resources. 7) Performance pressure: in an intelligent organization, every person is responsible for his own performance. When the members of an organization expect their needs to be answered the sense of accepting responsibility increases among members to meet these expectations. As a result each new member can feel this sense among the staff members.

There are different definitions of entrepreneurship some of which are briefly given. Timmons (1984) regards it as the creation of something new from nothing. Amit (1993, in Karbasi, 2006) regards entrepreneurship as directing resources towards capacities that create capital. To him entrepreneurs are those who do innovations, find business chances and create new resources so that they can benefit from these innovations in an uncertain environment.

Quartco and Hajets (2001) believe entrepreneurship is a process leading to satisfaction or new demand. In fact, it the creation of a set of unique resources for using opportunities. According to Baume entrepreneurship is the result of the clash of the individual features of entrepreneurs with the environment that they have grown in (Postigo, 2002). Schumpeter, the father of entrepreneurship gives a comprehensive definition of entrepreneurship. To him, entrepreneurship is the process of creative destruction and the engine of economic development. He regarded entrepreneurship as the provision of new product or services, creation of new methods and process of production, finding resources and new primary materials and the creation of new structures in industry (Ahmadpour Dariani, 1999). Although there have been provided a lot of definitions of entrepreneurship and entrepreneurs, probably there is no definition more comprehensive than the definition by Shum Peter in the available literature. In his book of 'Economic Development Theories', by distinguishing innovation from creation, he believed that the process of innovation and creation is the stage at which creations are applied and that creation is of importance and demands risk taking. He considered innovation as a criterion for entrepreneurship and that with the emergence of new entrepreneurs, some of the old ones will face failure and will be discarded from the economic circle. He calls this circle 'creative destruction' and considers entrepreneurship as the provision of new products or services, the creation of new process or methods, finding new resources and primary materials and the creation of new structures in industry (Ahmadpour Dariani, 1999).); Carland and associates (1984) collected different characteristics existing from the very beginning till 1984 some of which are mentioned bellow.

1- Creativity: Creativity is the ability in the creation of new ideas and these ideas may lead to the creation new products or services. In fact, creativity is a power latent in innovation.

2- Risk taking: it is moderate risks that can be controlled through personal attempts.

3- Independence: it is one of the characteristics much emphasized as provoking forces. Tendency towards independence is a motivating power. In fact independence is a factor that causes entrepreneurs actualize their dreams and therefore, freedom of action is the reward of entrepreneurship.

4- Motivation: entrepreneurs have characteristics called by psychologists as gained motivation, and do their job for the sake of I itself and not rewards or appreciations.

5- Determination: an entrepreneur always trusts his/her determination and protects himself/herself from any doubt and is aware of a strong talent inside him/her and is determined to responsibilities. 
6- Futurism: entrepreneurs have a good power to understand the future and to have an analytical understanding of environmental issues. They always think about their long term goals and their goals are not normally usual goals. With regard to the mentioned statements above, this study is investigating the relationship between organizational intelligence and entrepreneurship in educational managers and the faculty staff of the university.

\section{Methodology}

The general purpose of this study is to find out the relationship between organizational intelligence and entrepreneurship from the viewpoint of educational managers. This study uses a descriptive survey in data collection.

\section{Participants}

The statistical population of this research is 230 educational managers of university including faculty staff members and educational, research and executive managers. The number of participants studies in this research through head-counting is 202.

\section{Instruments}

Two instruments were used to collect data. The first one is Organizational Intelligence Questionnaire (Albercht, 2003, Abzari and Sattari Ghahfarkhi, 2007) and Entrepreneurship Questionnaire (Robins, 1889, in Moghimi, 2008, Ahmadpour Dariani, 1999). For ensuring the validity of the instruments, expert opinions were sought. Alpha Cronbach was also used to determine the validity of the instruments and the indexes achieved are 0.9 and 0.70 for the two instruments respectively. For the sake of data analysis in the descriptive statistics section, tables of frequency distribution, average, standard deviation were used. In the referential statistics, Pearson correlation analysis, stepwise regression analysis and structural equations were used.

\section{Results}

For the sake of the analysis of the relationship between variables correlation and regression and structural equations were used as described below.

Table 1: Results of Pearson Correlation between variables and components

\begin{tabular}{|c|c|c|c|c|c|c|c|}
\hline $\begin{array}{l}\text { pependent } \\
\text { Variable } \\
\text { Independent } \\
\text { Variable }\end{array}$ & Futurism & Determined & Motiration & Independence & $\begin{array}{l}\text { Risk } \\
\text { taking }\end{array}$ & Creativity & entrepreneurship \\
\hline Strategic Vision & 0.65 & 0.52 & 0.48 & 0.58 & 0.64 & 0.62 & 0.69 \\
\hline Shared Fate & 0.48 & 0.32 & 0.50 & 0.44 & 0.37 & 0.53 & 0.55 \\
\hline $\begin{array}{l}\text { Appetite for } \\
\text { Change }\end{array}$ & 0.67 & 0.56 & 0.68 & 0.67 & 0.64 & 0.66 & 0.76 \\
\hline Heart & 0.62 & 0.58 & 0.59 & 0.65 & 0.59 & 0.57 & 0.72 \\
\hline
\end{tabular}


A. Bakhshian, F. Hamidi, M. Ezati/ TJMCS Vol .3 No.4 (2011) 413 - 421

\begin{tabular}{|l|l|l|l|l|l|l|l|}
\hline $\begin{array}{l}\text { Alignment } \\
\text { \&Congruence }\end{array}$ & 0.72 & 0.60 & 0.69 & 0.63 & 0.62 & 0.68 & $\mathbf{0 . 7 7}$ \\
\hline $\begin{array}{l}\text { Knowledge } \\
\text { Deployment }\end{array}$ & 0.56 & 0.33 & 0.64 & 10.46 & 0.42 & 0.52 & $\mathbf{0 . 6 1}$ \\
\hline $\begin{array}{l}\text { Performance } \\
\text { Pressure }\end{array}$ & 0.54 & 0.51 & 0.58 & 0.60 & 0.49 & 0.54 & $\mathbf{0 . 6 5}$ \\
\hline $\begin{array}{l}\text { Organization } \\
\text { intelligence }\end{array}$ & $\mathbf{0 . 7 6}$ & $\mathbf{0 . 5 9}$ & $\mathbf{0 . 7 3}$ & $\mathbf{0 . 7 2}$ & $\mathbf{0 . 6 7}$ & $\mathbf{0 . 7 6}$ & $\mathbf{0 . 8 5}$ \\
\hline
\end{tabular}

The above table shows the correlation between OI and its components as independent variable and entrepreneurship and its components as a dependent variable. It is clear from the correlation coefficient of $\mathrm{R}=0,85$, there is a direct relationship between the variables and the correlation is high. High correlation coefficient between variables shows a significant relationship between all predictor and criterion variables. This shows the more the amount of OI the more the amount of entrepreneurship.

Table 2: Results of Stepwise Regression for Entrepreneurship as Dependent Variable

Model Summary

\begin{tabular}{|l|l|l|l|l|}
\hline Model & $\mathrm{R}$ & R Square & $\begin{array}{l}\text { Adjusted R } \\
\text { Square }\end{array}$ & $\begin{array}{l}\text { Std. Error of the } \\
\text { Estimate }\end{array}$ \\
\hline 1 & $.784^{\mathrm{a}}$ & .614 & .611 & 9.26458 \\
2 & $.854^{\mathrm{b}}$ & .729 & .725 & 7.79339 \\
3 & $.868^{\mathrm{c}}$ & .753 & .748 & 7.45565 \\
\hline
\end{tabular}

a. Predictors: (Constant), Alignment \&Congruence

b.Predictors:(Constant), Alignment\&Congruence, Heart

c.Predictors:(Constant),Alignment\&Congruence,Heart,Appetite for Change

ANOVA $^{a}$

\begin{tabular}{|ll|l|l|l|l|l|}
\hline Model & & Sum of Squares & df & Mean Square & F & Sig. \\
\hline 1 & Regression & 20880.307 & 1 & 20880.307 & 243.268 & $.000^{\mathrm{a}}$ \\
& Residual & 13132.364 & 153 & 85.832 & & \\
& Total & 34012.671 & 154 & & & \\
\hline 2 & Regression & 24780.652 & 2 & 12390.326 & 204.000 & $.000^{\mathrm{b}}$ \\
& Residual & 9232.019 & 152 & 60.737 & & \\
& Total & 34012.671 & 154 & & & \\
\hline 3 & Regression & 25619.082 & 3 & 8539.694 & 153.628 & $.000^{\mathrm{C}}$ \\
& Residual & 8393.589 & 151 & 55.587 & & \\
& Total & 34012.671 & 154 & & & \\
\hline
\end{tabular}

a. Predictors: (Constant), ), Alignment \&Congruence

b. Predictors: (Constant), Alignment\&Congruence, Heart

c. Predictors:(Constant),Alignment\&Congruence,Heart, Appetite for Change

d. Dependent Variable: entrepreneurship

The above table shows the stepwise multivariate regression analysis for predicting the criterion variable (entrepreneurship). As shown in the above table up to the third stage 3 variables were included in the regression equation. Alignment and congruence is the first variable that entered the equation and had the most effect on entrepreneurship with determination coefficient $\left(R^{2}=0.61\right)$, after this comes the variable heart with the 
determination coefficient $\left(R^{2}=0.11\right)$, and then comes the variable appetite for change with determination coefficient $\left(R^{2}=0.03\right)$. In total these three variables have shown 0.75 of changes of the entrepreneurship variable and the regression equation will be as follows: $\mathrm{y}=20.75+0.84 \mathrm{x}_{1}+1.28 \mathrm{x}_{2}+1.07 \mathrm{x}_{3}$

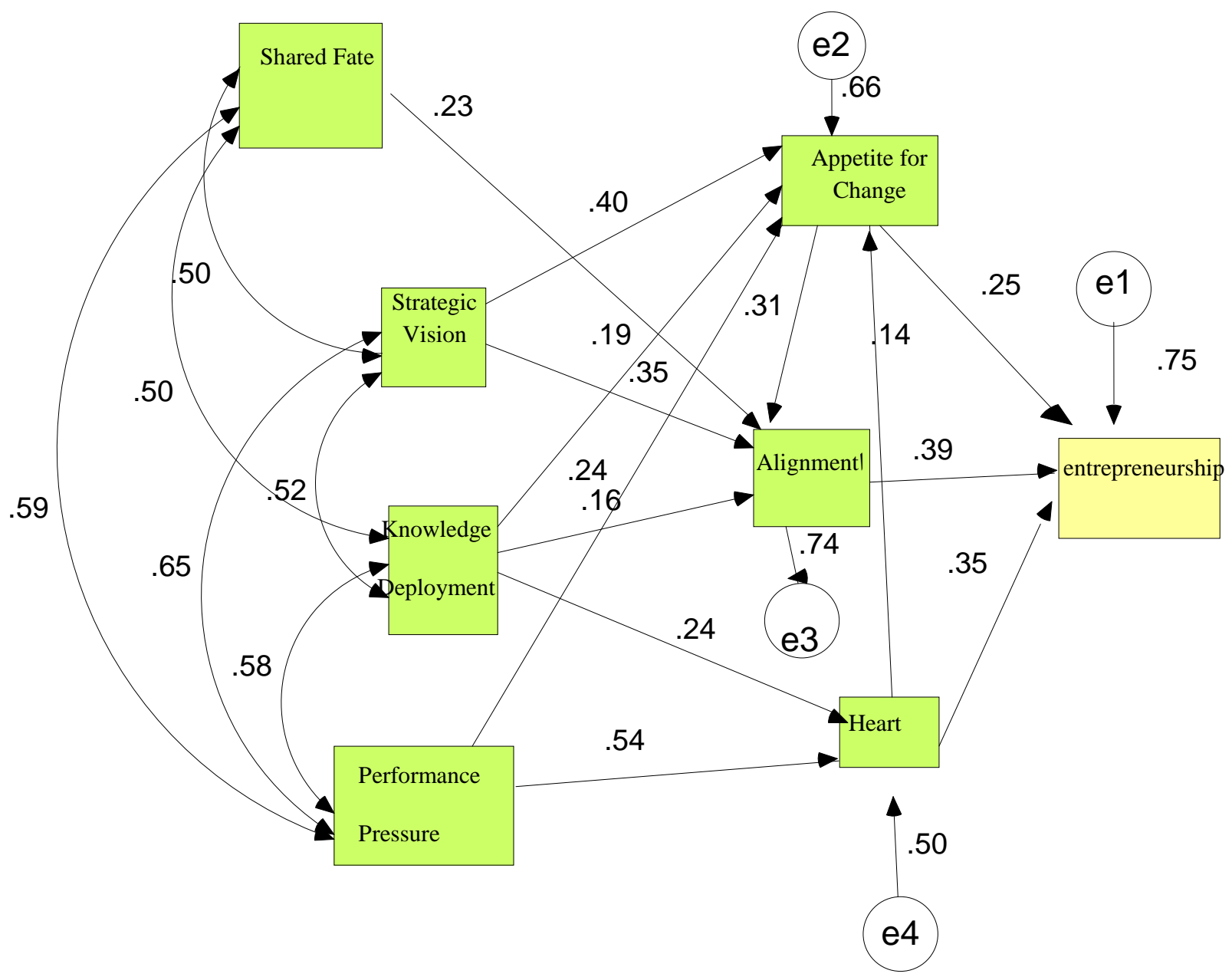

\section{Shape1: Empirical model of relationship between Organization Intelligence and Entrepreneurship components}

The above model shows direct and indirect relationship between organizational intelligence components and entrepreneurship. Alignment and congruence with a coefficient of, $\beta$ : 0.39 has the most effect on entrepreneurship followed by heart and appetite for change. Other variables indirectly have effects on entrepreneurship with a determination coefficient of 0.75 $\left(R^{2}\right.$. this means that 75 percent of changes in the dependent variable (entrepreneurship) is done through the existing variables in the model.

\section{Conclusion and recommendation}

In this research the relationship between OI and entrepreneurship from the perspective of university educational managers was studied. Based on the correlational test, there was a 
significant relationship between the two. In fact the more the OI in an organization, the more entrepreneurship will be $\mathrm{n}$ that organization. This result shows there is a significant relationship between OI components and entrepreneurship as dependent variable. It shows that correlation between the two variables is very high. As mentioned before, based on the Amos software an analytical-experimental model was presented for the relationship between dependent and independent variables. Standard coefficients of the two measurement models OI and entrepreneurship shows an acceptable correlation of 0.88.in addition, Beta Coefficient (0.88) of structural model (the relationship between OI and entrepreneurship) shows the high effect of the independent latent variable and dependent latent variable (entrepreneurship).

The component of alignment and congruence had the most significant effect on entrepreneurship followed by heart and appetite for change. Other variables have effects on entrepreneurship and through effects on these three variables. After that there are strategic perspectives and the application of knowledge. The determine coefficient of the model is 0.75. this means that 0.75 of the changes in the dependent variable (entrepreneurship) has been done through the existing variables in the model. Since there was no research done in the literature to show the relationship of these two models there is no chance to compare the findings of this hypothesis with those of other studies.

It should be mentioned some researchers have studied the relationship between OI and other variables. For example, the study by Liebowitz (2005) on OI and knowledge management supports this issue. Lefter and colleagues also found a significant relationship between OI and economic growth. The positive correlation between OI and organizational learning is also in line with the results of the study done by Halal (2006) and Schwaning (2001) as the more cooperation and harmony in a university is, the more organizational entrepreneurship exists. However, studies conducted by Ruhan and associates (2009) shows there is a positive relationship between organizational IQ and company performance. Baum and Smith (2011) in their research have studied the practical intelligence of entrepreneurs who had high potential. They found that practical intelligence of those entrepreneurs who have high potential is high. They also found a positive relationship between practical intelligence, learning style and investment growth.

Results of the study show that it can be claimed about the components OI and entrepreneurship that all the components OI are good representatives for entrepreneurship and one can use these components for entrepreneurship. From among components OI and alignment and congruence have the highest correlation with entrepreneurship and this states that the participation of managers and faculty staff in major decision makings is very important in increasing the entrepreneurship at university. Among the components OI performance pressure has the lowest correlation with entrepreneurship showing lack of harmony between managers and faculty members with their role and performance in the organization and this can lead to a decrease in organizational performance at university.

With respect to the results of the study and the positive opinion of managers and faculty members to OI and entrepreneurship it is suggested that each of the components and the different aspects of OI and entrepreneurship in universities and organizations be measured and assessed. This will increase the infrastructure of OI which is needed for becoming an organization with high OI and entrepreneurship. This will pave the ground for our movement towards our 20 year-perspective for the improvement of the country.

It seems that we should do two things for having a competent higher education system. One is to be careful at employing human forces as the human OI; next is that there should be an interaction between intelligent humans and intelligent educational instruments. 
Development of structures. Regulations, methods, and approaches that are necessary should be studied in line with variables under study. With regard to findings of this research based on the significant relationship of some components, it seems that some components such as alignment and congruence, heart and appetite for change need the most attention at universities.

\section{References}

1. Bostjan ,A. pordan.Igor(2008).Alliancess, corporate technological entrenership : Testing a model on manufacturing firms,technovation 28.

2. Abzari,M., and Sattari Ghahfarkhi, M.(2007).Relationship between Knowledge Management Sub-System in Learning Organization and Organization Intelligence Components. The First National Conference of Knowledge Management.

3. Ahmadpour Dariani, M (1999). Design and Description of Training Entrepreneur Managers in Industry. Thesis for Ph.D, humanities college,Tarbiat Modarres University.

4. Albrecht, K. (2003).Organizational intelligence survey preliminaryAssessment. Journal Institute Of Management, 1-7.

5. Albrecht.k.(2003)."The Power of minds at work : organizational intelligence in action".American Management.

6. Amit, R. et al., (1993), Challenges to theory development in entrepreneurship research, Journal of Management Studies, (30)(5).

7. Ashena,M., Marzban.A.,Taslimi.M (1997).Relationship between Social Capital and Organization Enterpreneurship. Farhang Modiriat Publication.

8. Baum, R.,.Smit.J(2011), The Practical Intelligence Of potential Entrepreneurs. email: jrbaum@rhsmith.umd.edu

9. Choo, C. W (1995), "Information management for an intelligent- organization: The art of environmental scanning", Medford, NJ: Learned Information.

10. Halal,W.E(1998). organization Intelligence: what is it,and how can manager use it?Retrieved,2007.from.http://www.bah.com.

11. Halal,W.E(2006). organization Intelligence. Melcrum publishing Itd

12. Lefter,V,Prejmerean,M.\&Vasilache.s.(2008).The dimension of organizational in Romanian companies-a capital perspective. Academy of economic studies.Bucharest.

13. Liebowitz, J., (2005), Entrepreneurship: Next century' sunirersity funding will come mostly from successful entrepreneur alumni. We should plan for than now.managementreview ,dec 95, vol.84 issue 12, Journal of Opera?onal Research,147,pp128-136.

14. Matsuda.T.(1992)."Organizational Intelligence:Its Significance as a Process and as a Product". Procceding of the International Conferencw on Economics/Management and Information Technology,Tokyo.Japan,August31-September 4.

15. Moghimi, S.M.(2008). A research Approach to: Organization and Management.Termeh Publication,PP160-162

16. Ruhan,A. Iijima ,Junichi. Ho Sho(2009). "A Study on Relationship between Organization Intelligence Quotient and Firm Performance . A comparison study between Japan and China. Tokyo Institute of Technology, Japan.

17. Ruhan,A. Iijima ,Junichi. Ho Sho(2009). "A Study on Relationship between Organization Intelligence Quotient and Firm Performance 
A. Bakhshian, F. Hamidi, M. Ezati/ TJMCS Vol .3 No.4 (2011) $413-421$

18. Schwaninger,m.(2001).Intelligent organization:an integrative framework. John wiley and sons, Itd.

19. Sexton.D\&Bowman.OF(2004) ,. Entrepreneurship: Theory,Process,Practice(Mason, $\mathrm{OH}$,South- Western Publishers).

20. vanvuuren,J.J(2003) , An anction learn approach to entrepreneurial creativity,innovation and opportunity finding",University of Pretoria.

21. Veryard , R.(2000). Component - Based Business Background Material , on Intelligenc . 